\title{
Application of Exopolysaccharide-Producing Cultures in Reduced-Fat Cheddar Cheese: Texture and Melting Properties*
}

\author{
S. Awad, ${ }^{1}$ † A. N. Hassan, ${ }^{1}$ and K. Muthukumarappan ${ }^{2}$ \\ ${ }_{1}^{1}$ Minnesota-South Dakota Dairy Foods Research Center, Dairy Science Department, and \\ ${ }^{2}$ Department of Agricultural and Biosystems Enginering, South Dakota State University, Brookings 57007
}

\begin{abstract}
Textural, melting, and sensory characteristics of reduced-fat Cheddar cheeses made with exopolysaccharide (EPS)-producing and nonproducing cultures were monitored during ripening. Hardness, gumminess, springiness, and chewiness significantly increased in the cheeses as fat content decreased. Cheese made with EPS-producing cultures was the least affected by fat reduction. No differences in hardness, springiness, and chewiness were found between young reduced fat cheese made with a ropy Lactococcus lactis ssp. cremoris [JFR1; the culture that produced reduced-fat cheese with moisture in the nonfat substance (MNFS) similar to that in its full-fat counterpart] and its fullfat counterpart. Whereas hardness of full-fat cheese and reduced-fat cheese made with JFR1 increased during ripening, a significant decrease in its value was observed in all other cheeses. After 6 mo of ripening, reduced fat cheeses made with all EPS-producing cultures maintained lower values of all texture profile analysis parameters than did those made with no EPS. Fat reduction decreased cheese meltability. However, no differences in meltability were found between the young full-fat cheese and the reduced-fat cheese made with the ropy culture JFR1. Both the aged full- and reduced-fat cheeses made with JFR1 had similar melting patterns. When heated, they both became soft and creamy without losing shape, whereas reduced-fat cheese made with no EPS ran and separated into greasy solids and liquid. No differences were detected by panelists between the textures of the full-fat cheese and reduced-fat cheese made with JFR1, both of which were
\end{abstract}

Received May 1, 2005.

Accepted July 4, 2005.

Corresponding author: Ashraf N. Hassan; e-mail: Ashraf.Hassan @sdstate.edu.

*Published with the approval of the director of the South Dakota Agricultural Experiment Station as Publication Number 3486 of the Journal Series. This research was supported in part by MinnesotaSouth Dakota Dairy Foods Research Center. Brookings, SD, and Midwest Dairy Association, St. Paul, MN.

$\dagger$ Current address: Department of Dairy Science and Technology, Faculty of Agriculture, Alexandria University, Egypt. less rubbery or firm, curdy, and crumbly than all other reduced-fat cheeses.

(Key words: reduced-fat Cheddar cheese, exopolysaccharide, texture, meltability)

Abbreviation key: EPS = exopolysaccharide, FFC = full-fat control cheese, MNFS = moisture in the nonfat substance, RF-3534 = reduced-fat cheese made with the moderate ropy strain Streptococcus thermophilus CHCC 3534, RF-5842 = reduced-fat cheese made with the EPS-negative genetic variant Streptococcus thermophilus CHCC 5842, RFC = reduced-fat control cheese, RF-JFR1 = reduced-fat cheese made with the ropy culture Lactococcus lactis ssp. cremoris JFR1, RFSlab $=$ reduced-fat cheese made with the capsule-forming nonropy strain Streptococcus thermophilus Slab.

\section{INTRODUCTION}

Fat reduction in cheese is associated with many textural and functional defects (Mistry, 2001). The high casein content in reduced-fat Cheddar cheese imparts a firm and rubbery body and texture (Mistry and Anderson, 1993; Mistry, 2001). These defects in reduced-fat cheeses are partially overcome by increasing the moisture content (Anderson et al., 1993). To increase the moisture level in reduced- and low-fat cheeses, several modifications in the cheese making procedure have been suggested. Increased rennet coagulation time, low cooking temperatures and time, high draining and milling $\mathrm{pH}$, homogenization of cream, and curd washing have been used (Mistry, 2001). Stabilizers, fat replacers, and sweet buttermilk have also been used to improve the quality of low-fat cheeses (Mayes et al., 1994; Drake et al., 1996; Mistry, 2001). However, modifications used to increase moisture levels in Cheddar cheese create several problems. For example, the higher $\mathrm{pH}$ of whey at draining and lower cook temperatures decrease chymosin retention and the extent of protein breakdown during ripening. Another outcome of these manufacturing conditions is the relatively higher level of calcium retention in cheese, which increases its firmness (Mistry, 2001). In addition, increasing the moisture in the nonfat substance (MNFS) in reduced- 
fat cheese to the same level found in full-fat cheeses makes it pasty and difficult to shred.

Exopolysaccharide (EPS)-producing cultures have been used to improve the rheological and textural characteristics of fermented dairy products (Perry et al., 1998; Hassan et al., 2004). Different types of EPS with varied functional properties are produced by lactic acid starter cultures (Cerning, 1990; Broadbent et al., 2003; Hassan et al., 2003). Exopolysaccharides increase the water-holding capacity of milk gel and interfere with protein-protein interactions, 2 functions required in low fat cheeses (Mistry, 2001). The selection of an EPSproducing culture to be used in making cheese depends on many factors such as functions of the EPS produced and cheese type and making conditions. For example, whereas moderate ropy cultures were suitable for making acid-coagulated soft cheese such as Karish (Hassan et al., 2004), nonropy EPS-producing cultures were appropriate for making rennet-coagulated cheeses (our unpublished data). The amount and type of EPS are influenced by the culture used and growth conditions (De Vuyst et al., 1998; Gorret et al., 2001). The ropy type of EPS might not be desirable in making Cheddar cheese because of the expected increase in whey viscosity, which limits its use. However, functions of the nonropy types of EPS in Cheddar cheese have not been reported.

We hypothesized that if EPS-producing cultures could increase the moisture level and improve texture of Cheddar cheese, reduced-fat cheese with similar characteristics to those of the full-fat types might be produced using traditional cheese making procedures without the need for modifications that are associated with several cheese defects. Our objectives were to study the effect of different types of EPS-producing cultures on the textural and functional properties of reduced-fat Cheddar cheese made using the traditional Cheddar cheese making protocol.

\section{MATERIALS AND METHODS}

\section{Cultures}

An EPS-producing moderate ropy Streptococcus thermophilus CHCC 3534 and its EPS-negative genetic variant Streptococcus thermophilus CHCC 5842 (Chr. Hansen, Hørsholm, Denmark), a capsule-forming nonropy Streptococcus thermophilus (Slab; Hassan et al., 1995), and a ropy Lactococcus lactic spp. cremoris (JFR1; Hassan et al., 2003) were used in this study. None of the EPS-producing cultures used in this study increased the viscosity of the Cheddar cheese whey (data not shown). Culture preparation was done as previously described (Awad et al., 2005). Commercial direct to vat set Cheddar culture (DVS 850) was obtained from Chr. Hansen Laboratory (Milwaukee, WI).

\section{Cheese Making}

Raw milk was obtained from the Dairy Research and Training Facility at South Dakota State University (Brookings). Cheddar cheese was manufactured from standardized (2\% reduced fat or $3.6 \%$ full fat), pasteurized $\left(63^{\circ} \mathrm{C}\right.$ for $30 \mathrm{~min}$ and cooled to $\left.31^{\circ} \mathrm{C}\right)$ milk. Cheese milk (100 kg) was assigned to a double-O cheese vat (Kusel Equipment Co., Watertown, WI). The following 6 treatments of cheese were made: 1$)$ FFC = full fat made using the commercial Cheddar starter culture (DVS 850; 0.015\% wt/wt); 2) $\mathbf{R F C ~ = ~ r e d u c e d ~ f a t ~ m a d e ~}$ using the commercial Cheddar starter culture (DVS 850; 0.015\% wt/wt); 3) RF-JFR1 = reduced-fat made with the ropy strain Lactococcus lactis spp. cremoris JFR1 (2\% vol/wt); 4) RF-Slab = reduced fat made with a capsule-forming nonropy Streptococcus thermophilus $(0.4 \% \mathrm{vol} / \mathrm{wt})$ plus the commercial culture $(0.011 \% \mathrm{wt} /$ wt); 5) RF-3534 = reduced fat made with EPS-producing Streptococcus thermophilus CHCC 3534 (0.4\% vol/ wt) plus the commercial culture $(0.011 \% \mathrm{wt} / \mathrm{wt})$; and 6) RF-5842 = reduced fat made with the EPS-negative genetic variant of CHCC 3534 (Streptococcus thermophilus CHCC 5842) (0.4\% vol/wt) plus the commercial culture $(0.011 \% \mathrm{wt} / \mathrm{wt})$. All 6 cultures produced similar acidification rate and cheese making time. Cheddar cheese was made as described by Awad et al. (2005). Curd was cooked to $39^{\circ} \mathrm{C}$ and held at this temperature for $30 \mathrm{~min}$. The milling $\mathrm{pH}$ was 5.4 and salt level was $1.7 \%$.

\section{Texture Profile Analysis}

Cheeses were cut into cylindrical samples of $20 \times 20$ mm using a cork borer \#12 and a wire cutter, placed in plastic bags, sealed (to prevent dehydration), and stored at $20^{\circ} \mathrm{C}$ for $1 \mathrm{~h}$. Samples were obtained from the middle of the whole cheese block to avoid surface effects. A 2-bite compression test was performed using the Instron Universal Testing Machine (model SINTECH 2/ D; MTS Systems Corp., Eden Prairie, MN) with a 45.4$\mathrm{kg}$ load cell. A 25\% compression test was used and the crosshead speed was $50 \mathrm{~mm} / \mathrm{min}$. Hardness, cohesiveness, gumminess, chewiness, and adhesiveness were determined in triplicate from the texture profile curve as described by Bourne (1978).

\section{Estimating Softening Point and Flow Characteristics}

A cheese block was cut into slices ( $\sim \mathrm{mm}$ thickness) perpendicular to the long axis of the block using an 
electric food slicer. Cylindrical pieces ( $\sim 30 \mathrm{~mm}$ diameter and $5 \mathrm{~g}$ ) were cut out with a cork borer. The modified squeeze-flow apparatus described by Muthukumarappan et al. (1999) was used to study the softening properties of cheese. The test was performed by placing the cylindrical cheese pieces on a sample platform and lowering the circular disk to be in continuous contact with the cheese. The cheese was covered with mineral oil to prevent dehydration, and a constant oven temperature of $70^{\circ} \mathrm{C}$ was used. The softening temperature, softening time, and flow rate were calculated as described by Muthukumarappan et al. (1999).

\section{Sensory Evaluation}

Three faculty members experienced in evaluating cheese from the Dairy Science Department, South Dakota State University (Brookings), graded coded samples of cheese at 1,3, and 6 mo. At each session, 6 cheeses were evaluated. Each individual was given 4 blocks $(8 \times 2 \times 2 \mathrm{~cm})$ of cheese per sample. Samples were presented in identical plastic sample cups sealed with plastic lids and identified by a random 3-digit number. The coded samples were randomly presented. The rating of 12 attributes included flavor (acid, bitter, or flat) and body and texture characteristics (crumbly, curdy, grainy, rubbery/firm, short, smooth, and weak) were recorded on a 1- to 9-point scale. Flavor and body and texture scores of $1=$ none, $5=$ definite, and $9=$ pronounced. Overall flavor and body and texture scores of $1=$ poor, $5=$ average, and $9=$ excellent.

\section{Statistical Analyses}

Data reported are the average of 3 measurements per replicate. Cheeses were made 3 times. The GLM procedure using the SAS package (SAS Institute, 1999) was used for ANOVA. Means separation was conducted using Duncan's multiple range test. Differences were considered significant at $P<0.05$.

\section{RESULTS AND DISCUSSION}

\section{Cheese pH and Composition}

The composition of Cheddar cheese made with different fat levels and starter cultures is summarized in Table 1. Fat in DM and salt in moisture were significantly higher in FFC than in all reduced-fat cheeses. Fat in DM was not significantly different $(P>0.05)$ among all reduced-fat cheeses. Cheese made with the ropy culture JFR1 had lower $(P<0.05)$ salt in moisture levels than all other reduced-fat cheeses. The FFC and RF-JFR1 cheeses contained a similar level of MNFS, which was higher than that in all other reduced fat cheeses (Table 1). This is significant because slight differences in moisture of Cheddar cheese may cause major differences in its rheological parameters (De Jong, 1978). There were no differences $(P>0.05)$ in the $\mathrm{pH}$ among all cheeses at $\mathrm{d} 1$ after manufacture.

\section{Textural Characteristics: Hardness}

The changes in hardness values during cheese ripening are shown in Table 2. Reduction of fat increased the hardness of all fresh cheeses except for RF-JFR1, which did not differ $(P>0.05)$ from the FFC. Among all reduced-fat cheeses, RF-JFR1 contained the highest moisture level (Table 1) due to the ability of EPS to bind water. Results indicated that the hardness of fresh cheese increases as the total filler within the network (fat plus moisture) and the MNFS decrease and the protein level increases. The increase in moisture resulting from fat reduction did not offset the decrease in fat except in RF-JFR1, which did not differ $(P>$ 0.05 ) in hardness from FFC. Although water acts as a lubricant or plasticizer between proteins, higher moisture content of cheeses does not necessarily soften the protein matrix (Bryant et al., 1995). The structural matrix of cheese is a cross-linked casein-calcium phosphate network in which fat globules are physically entrapped (Prentice et al., 1993). The protein matrix is elastic when the casein is largely intact (Jameson, 1990). The reduced hardness of RF-JFR1 is related not only to the relatively high MNFS but also to the modification in the protein network caused by the presence of EPS. Exopolysaccharide interferes with protein-protein interactions, resulting in reduced firmness (Hassan and Frank, 1997). Soft cheese made with EPS-producing cultures exhibited a porous structure in which the large pores were associated with visible EPS (Hassan et al., 2004). However, a compact structure with small pores was seen in cheese made with EPS-nonproducing cultures (Hassan et al., 2004). Cryo-scanning electron microscopy observations showed that EPS was associated with large pores within the microstructure of reduced-fat Cheddar cheese (Hassan and Awad, 2005).

Cheeses made with the adjunct cultures of either the capsule-forming nonropy (RF-Slab) or the moderate ropy strain of Streptococcus thermophilus (RF-3534) exhibited similar hardness to those made with no EPS. This indicated that the amount or the type of EPS produced by those cultures did not allow differences to be seen. The Streptococcus thermophilus CHCC3534 used in this study has been reported to reduce the rigidity of an acid-coagulated soft cheese (Hassan et al., 2004). In acid-coagulated cheese, enough time is given to the culture to produce EPS even before the gelation initiates. This EPS interferes with the network formation, 
Table 1. Chemical composition (\%), $\mathrm{pH}$, and actual yield (\%) of cheeses at $\mathrm{d} 1$ after manufacture. ${ }^{1}$

\begin{tabular}{llllllll}
\hline & \multicolumn{5}{c}{ Composition and characteristics $^{2}$} & \multirow{2}{*}{$\begin{array}{c}\text { Actual } \\
\text { Treatment }\end{array}$} \\
\cline { 2 - 6 } & FDM & SM & MNFS & DM & M + F & pH & yield \\
\hline FFC & $53.2^{\mathrm{a}}$ & $3.7^{\mathrm{a}}$ & $58.5^{\mathrm{a}}$ & $60.3^{\mathrm{a}}$ & $71.8^{\mathrm{a}}$ & $5.24^{\mathrm{a}}$ & $10.4^{\mathrm{a}}$ \\
RFC & $35.2^{\mathrm{b}}$ & $3.4^{\mathrm{b}}$ & $53.4^{\mathrm{c}}$ & $57.4^{\mathrm{b}}$ & $62.8^{\mathrm{c}}$ & $5.26^{\mathrm{a}}$ & $8.5^{\mathrm{d}}$ \\
RF-JFR1 & $35.9^{\mathrm{b}}$ & $3.1^{\mathrm{c}}$ & $58.4^{\mathrm{a}}$ & $52.7^{\mathrm{c}}$ & $66.2^{\mathrm{b}}$ & $5.22^{\mathrm{a}}$ & $9.1^{\mathrm{b}}$ \\
RF-Slab & $35.5^{\mathrm{b}}$ & $3.3^{\mathrm{b}}$ & $54.9^{\mathrm{b}}$ & $56.0^{\mathrm{b}}$ & $63.9^{\mathrm{c}}$ & $5.21^{\mathrm{a}}$ & $8.8^{\mathrm{c}}$ \\
RF-3534 & $35.5^{\mathrm{b}}$ & $3.4^{\mathrm{b}}$ & $54.3^{\mathrm{bc}}$ & $56.6^{\mathrm{b}}$ & $63.5^{\mathrm{c}}$ & $5.23^{\mathrm{a}}$ & $8.6^{\mathrm{d}}$ \\
RF-5842 & $35.0^{\mathrm{b}}$ & $3.3^{\mathrm{b}}$ & $53.4^{\mathrm{c}}$ & $57.3^{\mathrm{b}}$ & $62.8^{\mathrm{c}}$ & $5.25^{\mathrm{a}}$ & $8.5^{\mathrm{d}}$ \\
\hline
\end{tabular}

a,b,c,d Means within a column with no common superscript differ $(P<0.05)$.

${ }^{1}$ From Awad et al. (2005).

${ }^{2} \mathrm{FDM}=$ Fat in DM; $\mathrm{SM}=$ salt in moisture; $\mathrm{MNFS}=$ noisture in the nonfat substance; $\mathrm{M}+\mathrm{F}=$ moisture plus fat.

${ }^{3} \mathrm{FFC}=$ Full-fat control; RFC = reduced-fat control; RF-JFR1 = reduced-fat cheese made with the ropy culture Lactococcus lactis ssp. cremoris JFR1; RF-Slab = reduced-fat cheese made with the capsule-forming nonropy strain Streptococcus thermophilus Slab; RF-3534 = reduced-fat cheese made with the moderate ropy strain Streptococcus thermophilus CHCC 3534; and RF-5842 = reduced-fat cheese made with the EPSnegative genetic variant Streptococcus thermophilus CHCC 5842.

which is reflected by the hardness of the final cheese. However, in Cheddar cheese, most of the EPS is produced after the protein network has already formed. Therefore, in Cheddar, the main roles of EPS would be water binding and interference with protein-protein interactions after the formation of the network. It was not possible to increase the level of the adjunct $S$. thermophilus cultures and maintain the $\mathrm{pH}$ at the desirable level.
After 1 mo of ripening, a sharp decrease $(P<0.05)$ in the hardness of all reduced-fat cheeses except RFJFR1 was observed (Table 2). The FFC and RF-JFR1 were the only cheeses that did not show a decrease in hardness during the first month of ripening. The decrease in hardness during the early stages of ripening is due to the rapid transformation of the rubbery texture of young cheese into a smoother and softer product (Lawrence and Gilles, 1987). This early change in the

Table 2. Hardness, cohesiveness, and adhesiveness of reduced- and full-fat Cheddar cheeses during ripening.

\begin{tabular}{lcccccc}
\hline \multirow{2}{*}{$\begin{array}{l}\text { Ripening } \\
\text { time (mo) }\end{array}$} & \multicolumn{5}{c}{ Treatment $^{1}$} \\
\cline { 2 - 6 } & FFC & RFC & RF-JFR1 & RF-Slab & RF-3534 & RF-5842 \\
\hline Hardness (N) & & & & & \\
0 & $13.15^{\mathrm{c}, \mathrm{E}}$ & $23.39^{\mathrm{a}, \mathrm{A}}$ & $15.69^{\mathrm{c}, \mathrm{C}}$ & $20.39^{\mathrm{b}, \mathrm{A}}$ & $21.19^{\mathrm{ab}, \mathrm{A}}$ & $22.11^{\mathrm{ab}, \mathrm{A}}$ \\
1 & $14.44^{\mathrm{c}, \mathrm{D}}$ & $19.39^{\mathrm{a}, \mathrm{D}}$ & $15.25^{\mathrm{c}, \mathrm{C}}$ & $17.59^{\mathrm{ab}, \mathrm{C}}$ & $17.43^{\mathrm{b}, \mathrm{D}}$ & $17.95^{\mathrm{ab}, \mathrm{C}}$ \\
2 & $18.97^{\mathrm{bc}, \mathrm{B}}$ & $21.35^{\mathrm{a}, \mathrm{B}}$ & $18.70^{\mathrm{bc}, \mathrm{A}}$ & $18.40^{\mathrm{c}, \mathrm{B}}$ & $20.41^{\mathrm{ab}, \mathrm{B}}$ & $21.01^{\mathrm{ab}, \mathrm{A}}$ \\
4 & $19.80^{\mathrm{ab}, \mathrm{A}}$ & $20.69^{\mathrm{a}, \mathrm{C}}$ & $17.26^{\mathrm{d}, \mathrm{B}}$ & $15.61^{\mathrm{e}, \mathrm{D}}$ & $18.05^{\mathrm{cd}, \mathrm{C}}$ & $18.81^{\mathrm{bc}, \mathrm{B}}$ \\
6 & $15.28^{\mathrm{c}, \mathrm{C}}$ & $20.13^{\mathrm{a}, \mathrm{C}}$ & $17.05^{\mathrm{b}, \mathrm{B}}$ & $16.40^{\mathrm{bc}, \mathrm{D}}$ & $17.72^{\mathrm{b}, \mathrm{CD}}$ & $19.78^{\mathrm{a}, \mathrm{B}}$ \\
Cohesiveness (ratio) & & & & & & \\
0 & $0.76^{\mathrm{b}, \mathrm{B}}$ & $0.89^{\mathrm{a}, \mathrm{A}}$ & $0.85^{\mathrm{a}, \mathrm{A}}$ & $0.87^{\mathrm{a}, \mathrm{A}}$ & $0.88^{\mathrm{a}, \mathrm{A}}$ & $0.90^{\mathrm{a}, \mathrm{A}}$ \\
1 & $0.77^{\mathrm{ab}, \mathrm{B}}$ & $0.83^{\mathrm{a}, \mathrm{B}}$ & $0.78^{\mathrm{ab}, \mathrm{B}}$ & $0.81^{\mathrm{a}, \mathrm{B}}$ & $0.68^{\mathrm{b}, \mathrm{C}}$ & $0.70^{\mathrm{b}, \mathrm{C}}$ \\
2 & $0.82^{\mathrm{b}, \mathrm{A}}$ & $0.91^{\mathrm{a}, \mathrm{A}}$ & $0.85^{\mathrm{a}, \mathrm{A}}$ & $0.83^{\mathrm{a}, \mathrm{AB}}$ & $0.85^{\mathrm{a}, \mathrm{A}}$ & $0.86^{\mathrm{a}, \mathrm{A}}$ \\
4 & $0.62^{\mathrm{d}, \mathrm{C}}$ & $0.82^{\mathrm{a}, \mathrm{B}}$ & $0.80^{\mathrm{b}, \mathrm{B}}$ & $0.71^{\mathrm{c}, \mathrm{C}}$ & $0.79^{\mathrm{b}, \mathrm{B}}$ & $0.79^{\mathrm{b}, \mathrm{B}}$ \\
6 & $0.44^{\mathrm{d}, \mathrm{D}}$ & $0.79^{\mathrm{a}, \mathrm{C}}$ & $0.67^{\mathrm{b}, \mathrm{C}}$ & $0.66^{\mathrm{b}, \mathrm{D}}$ & $0.70^{\mathrm{b}, \mathrm{C}}$ & $0.81^{\mathrm{a}, \mathrm{B}}$ \\
Adhesiveness (J) & & & & & & \\
0 & $0.10^{\mathrm{c}, \mathrm{B}}$ & $0.18^{\mathrm{ab}, \mathrm{A}}$ & $0.21^{\mathrm{a}, \mathrm{A}}$ & $0.16^{\mathrm{b}, \mathrm{B}}$ & $0.17^{\mathrm{b}, \mathrm{B}}$ & $0.18^{\mathrm{ab}, \mathrm{A}}$ \\
1 & $0.09^{\mathrm{c}, \mathrm{C}}$ & $0.14^{\mathrm{abc}, \mathrm{B}}$ & $0.17^{\mathrm{a}, \mathrm{B}}$ & $0.11^{\mathrm{bc}, \mathrm{C}}$ & $0.16^{\mathrm{ab}, \mathrm{B}}$ & $0.16^{\mathrm{ab}, \mathrm{A}}$ \\
2 & $0.10^{\mathrm{b}, \mathrm{B}}$ & $0.14^{\mathrm{a}, \mathrm{B}}$ & $0.10^{\mathrm{b}, \mathrm{C}}$ & $0.10^{\mathrm{b}, \mathrm{C}}$ & $0.12^{\mathrm{ab}, \mathrm{C}}$ & $0.14^{\mathrm{a}, \mathrm{B}}$ \\
4 & $0.10^{\mathrm{b}, \mathrm{C}}$ & $0.07^{\mathrm{c}, \mathrm{D}}$ & $0.09^{\mathrm{b}, \mathrm{D}}$ & $0.07^{\mathrm{c}, \mathrm{D}}$ & $0.12^{\mathrm{a}, \mathrm{C}}$ & $0.07^{\mathrm{c}, \mathrm{D}}$ \\
6 & $0.21^{\mathrm{a}, \mathrm{A}}$ & $0.10^{\mathrm{c}, \mathrm{C}}$ & $0.19^{\mathrm{b}, \mathrm{A}}$ & $0.18^{\mathrm{b}, \mathrm{A}}$ & $0.21^{\mathrm{a}, \mathrm{A}}$ & $0.11^{\mathrm{c}, \mathrm{C}}$ \\
\hline
\end{tabular}

${ }^{\mathrm{a}-\mathrm{e}}$ Means within a row with no common lowercase superscript differ $(P<0.05)$.

${ }^{\mathrm{A}-\mathrm{E}}$ Means within a column with no common uppercase superscript $\operatorname{differ}(P<0.05)$.

${ }^{1} \mathrm{FFC}=$ Full-fat control; RFC = reduced-fat control; RF-JFR1 = reduced-fat cheese made with the ropy culture Lactococcus lactis ssp. cremoris JFR1; RF-Slab = reduced-fat cheese made with the capsule-forming nonropy strain Streptococcus thermophilus Slab; RF-3534 = reduced-fat cheese made with the moderate ropy strain Streptococcus thermophilus CHCC 3534; and RF-5842 = reduced-fat cheese made with the EPSnegative genetic variant Streptococcus thermophilus CHCC 5842. 
texture is attributed to a number of factors such as proteolysis of casein network by rennet (Lucey et al., 2003), increasing protein hydration by absorbing serum from the fat-serum channels (McMahon et al., 1999; Guinee, 2002), and solubilization of colloidal calcium phosphate (Lucey et al., 2003). Water redistribution, which occurs mainly during the first few weeks of ripening (McMahon et al., 1999), seemed to play a major role in cheese softening. Microstructural observations showed that water redistribution during ripening was less pronounced in both FFC and RF-JFR1 than in the other reduced-fat cheeses (Hassan and Awad, 2005).

After 2 and 4 mo of ripening, the hardness started to increase again after the sharp decrease noticed in the first few weeks. The increase in hardness during ripening might result from the reduction in the level of free water, which increases cheese resistance to deformation (McMahon et al., 1999; Beal and Mittal, 2000).

The 6-mo-old FFC and RF-JFR1 were harder than the fresh cheeses, whereas the opposite was observed in all other reduced-fat cheeses (aged cheeses were softer than the fresh ones). The higher rigidity of aged, fullfat Cheddar cheese compared with the reduced-fat cheese has been previously reported (Drake et al., 1996; Guinee et al., 2000). It is an interesting observation that changes in hardness of both FFC and RF-JFR1 cheeses followed the same pattern, and were different from those in all other cheeses. Both cheeses showed the least changes in hardness during the first month of ripening, and they were the only 2 treatments that produced aged cheeses that were harder than the fresh ones. However, the mechanism by which hardness is developed in the 2 types of cheeses seems to be different. The EPS produced by RF-JFR1 form a 3-D network (Hassan et al., 2003; Hassan and Awad, 2005), which could entrap a significant amount of water, resulting in a lower level of water available for protein hydration and a firmer network. The addition of a carbohydratebased mimetic has also produced Cheddar cheese that was firmer than the control (Ma et al., 1997). The microstructural observations of full-fat cheese showed that as cheese aged, less expressible serum resulted in more fat-protein interactions (Hassan and Awad, 2005). Such interactions might have increased hardness of FFC during ripening.

\section{Cohesiveness}

Cohesiveness is the strength of internal bonds making up the body of the product (Szczesniak et al., 1963; Bourne, 1978). Table 2 shows changes in cohesiveness of cheeses during ripening. Cohesiveness was similar among reduced-fat cheeses. Fat reduction increased $(P$
$<0.05$ ) cohesiveness of fresh cheese. Bryant et al. (1995) also reported that reduced-fat cheeses were more cohesive than were full-fat cheeses. None of the EPS-producing cultures reduced cohesiveness of the reduced-fat cheeses. The nature of the protein matrix and the extent of fat dispersion contribute to cohesiveness or the tendency of cheese to adhere to itself. During ripening, cohesiveness decreased $(P<0.05)$ in all cheeses. After 6 mo of ripening, FFC was the least cohesive, followed by reduced-fat cheeses made with EPS-producing cultures. Proteolysis disrupts the structural integrity of the protein matrix, leading to reduced cohesiveness (Irudayaraj et al., 1999). Proteolysis was higher in the less cohesive cheeses (Awad et al., 2005).

\section{Adhesiveness}

Adhesiveness is the work required to pull cheese away from a surface (e.g., tongue, teeth, palate) (Szczesniak et al., 1963; Bourne, 1978). Fat reduction increased $(P<0.05)$ adhesiveness of fresh cheeses (Table 2$)$. There was a consistent decline in the adhesiveness of all cheeses except the full-fat type over the first 4 mo of ripening. However, a sharp increase in the adhesiveness was observed in all cheeses between mo 4 and 6 . Adhesiveness increases with increasing ability of proteins to interact with water (Pastorino et al., 2003), which might take place during ripening. After 6 mo of ripening, both FFC and reduced-fat cheeses made with EPS-producing cultures had much higher adhesiveness than reduced-fat cheeses made with no EPS. Bryant et al. (1995) reported that adhesiveness of a 3-mo-old Cheddar cheese decreased with a decrease in the fat content. However, Olson and Johnson (1990) reported that low-fat cheeses exhibited a higher degree of stickiness when masticated.

\section{Springiness}

Springiness is the rate at which a deformed material returns to its original shape on removal of the deforming force (Szczesniak et al., 1963; Bourne, 1978). This parameter was lower in fresh FFC and RF-JFR1 than in the RFC cheese (Table 3). There was a sharp decrease in springiness in all cheeses between mo 4 and 6 , with FFC representing the lowest value. This decline in springiness may be due to the hydrolysis of para $\kappa$-caseinate molecules, which are responsible for the springiness of cheese curd (Kanawjia et al., 1995).

\section{Gumminess}

Gumminess is the energy required to disintegrate a semisolid food for swallowing (Szczesniak et al., 1963; 
Table 3. Springiness, gumminess, and chewiness of reduced and full fat Cheddar cheeses during ripening.

\begin{tabular}{|c|c|c|c|c|c|c|}
\hline \multirow{2}{*}{$\begin{array}{l}\text { Ripening } \\
\text { time (mo) }\end{array}$} & \multicolumn{6}{|c|}{ Treatment $^{1}$} \\
\hline & FFC & $\mathrm{RFC}$ & RF-JFR1 & RF-Slab & RF-3534 & RF-5842 \\
\hline \multicolumn{7}{|c|}{ Springiness (mm) } \\
\hline 0 & $4.29^{\mathrm{b}, \mathrm{B}}$ & $4.67^{\mathrm{a}, \mathrm{A}}$ & $4.29^{\mathrm{b}, \mathrm{B}}$ & $4.40^{\mathrm{ab}, \mathrm{A}}$ & $4.49^{\mathrm{ab}, \mathrm{A}}$ & $4.48^{\mathrm{ab}, \mathrm{A}}$ \\
\hline 1 & $4.42^{\mathrm{b}, \mathrm{AB}}$ & $4.73^{\mathrm{a}, \mathrm{A}}$ & $4.39^{\mathrm{b}, \mathrm{AB}}$ & $4.52^{\mathrm{ab}, \mathrm{A}}$ & $4.44^{\mathrm{ab}, \mathrm{A}}$ & $4.51^{\mathrm{ab}, \mathrm{A}}$ \\
\hline 2 & $4.49^{\mathrm{a}, \mathrm{A}}$ & $4.48^{\mathrm{a}, \mathrm{A}}$ & $4.64^{\mathrm{a}, \mathrm{A}}$ & $4.67^{\mathrm{a}, \mathrm{A}}$ & $4.35^{\mathrm{a}, \mathrm{B}}$ & $4.36^{\mathrm{a}, \mathrm{B}}$ \\
\hline 4 & $4.24^{\mathrm{c}, \mathrm{B}}$ & $4.45^{\mathrm{ab}, \mathrm{A}}$ & $4.47^{\mathrm{a}, \mathrm{A}}$ & $4.40^{\mathrm{b}, \mathrm{A}}$ & $4.44^{\mathrm{ab}, \mathrm{AB}}$ & $4.42^{\mathrm{ab}, \mathrm{AB}}$ \\
\hline 6 & $1.55^{\mathrm{c}, \mathrm{C}}$ & $2.81^{\mathrm{a}, \mathrm{B}}$ & $2.12^{\mathrm{b}, \mathrm{C}}$ & $2.09^{\mathrm{b}, \mathrm{B}}$ & $2.31^{\mathrm{b}, \mathrm{C}}$ & $2.83^{\mathrm{a}, \mathrm{C}}$ \\
\hline \multicolumn{7}{|c|}{ Gumminess $(\mathrm{N})$} \\
\hline 0 & $10.05^{\mathrm{d}, \mathrm{D}}$ & $20.73^{\mathrm{a}, \mathrm{A}}$ & $13.41^{\mathrm{c}, \mathrm{B}}$ & $17.67^{\mathrm{b}, \mathrm{A}}$ & $18.59^{\mathrm{ab}, \mathrm{A}}$ & $19.96^{\mathrm{ab}, \mathrm{A}}$ \\
\hline 1 & $11.15^{\mathrm{c}, \mathrm{C}}$ & $16.16^{\mathrm{a}, \mathrm{C}}$ & $12.01^{\mathrm{bc}, \mathrm{C}}$ & $14.27^{\mathrm{ab}, \mathrm{C}}$ & $11.92^{\mathrm{bc}, \mathrm{D}}$ & $12.56^{\mathrm{bc}, \mathrm{D}}$ \\
\hline 2 & $15.52^{\mathrm{b}, \mathrm{A}}$ & $19.40^{\mathrm{a}, \mathrm{B}}$ & $15.27^{\mathrm{b}, \mathrm{A}}$ & $16.41^{\mathrm{ab}, \mathrm{B}}$ & $17.35^{\mathrm{ab}, \mathrm{B}}$ & $18.01^{\mathrm{ab}, \mathrm{A}}$ \\
\hline 4 & $12.34^{\mathrm{c}, \mathrm{B}}$ & $16.92^{\mathrm{a}, \mathrm{C}}$ & $13.77^{\mathrm{b}, \mathrm{B}}$ & $11.15^{\mathrm{d}, \mathrm{D}}$ & $14.18^{\mathrm{b}, \mathrm{C}}$ & $14.93^{\mathrm{b}, \mathrm{C}}$ \\
\hline 6 & $6.67^{\mathrm{d}, \mathrm{E}}$ & $15.93^{\mathrm{a}, \mathrm{C}}$ & $11.42^{\mathrm{bc}, \mathrm{D}}$ & $10.78^{\mathrm{c}, \mathrm{D}}$ & $12.41^{\mathrm{b}, \mathrm{D}}$ & $16.05^{\mathrm{a}, \mathrm{B}}$ \\
\hline \multicolumn{7}{|c|}{ Chewiness (J) } \\
\hline 0 & $43.02^{\mathrm{c}, \mathrm{B}}$ & $97.28^{\mathrm{a}, \mathrm{A}}$ & $57.59^{\mathrm{c}, \mathrm{B}}$ & $77.77^{\mathrm{b}, \mathrm{A}}$ & $83.48^{\mathrm{ab}, \mathrm{A}}$ & $89.59^{\mathrm{ab}, \mathrm{A}}$ \\
\hline 1 & $49.32^{\mathrm{c}, \mathrm{B}}$ & $76.29^{\mathrm{a}, \mathrm{B}}$ & $52.75^{\mathrm{bc}, \mathrm{B}}$ & $64.34^{\mathrm{b}, \mathrm{B}}$ & $52.87^{\mathrm{bc}, \mathrm{D}}$ & $56.64^{\mathrm{bc}, \mathrm{C}}$ \\
\hline 2 & $69.80^{\mathrm{c}, \mathrm{A}}$ & $87.05^{\mathrm{a}, \mathrm{A}}$ & $74.24^{\mathrm{bc}, \mathrm{A}}$ & $71.30^{\mathrm{bc}, \mathrm{A}}$ & $75.62^{\mathrm{ab}, \mathrm{B}}$ & $78.47^{\mathrm{ab}, \mathrm{A}}$ \\
\hline 4 & $52.41^{\mathrm{c}, \mathrm{B}}$ & $75.70^{\mathrm{a}, \mathrm{B}}$ & $61.39^{\mathrm{b}, \mathrm{B}}$ & $49.11^{\mathrm{c}, \mathrm{C}}$ & $62.75^{\mathrm{b}, \mathrm{C}}$ & $66.31^{\mathrm{b}, \mathrm{B}}$ \\
\hline 6 & $10.34^{\mathrm{d}, \mathrm{C}}$ & $45.20^{\mathrm{a}, \mathrm{C}}$ & $24.55^{\mathrm{c}, \mathrm{C}}$ & $22.54^{\mathrm{c}, \mathrm{D}}$ & $28.57^{\mathrm{b}, \mathrm{E}}$ & $45.51^{\mathrm{a}, \mathrm{D}}$ \\
\hline
\end{tabular}

${ }^{\mathrm{a}-\mathrm{d}}$ Means within a row with no common lowercase superscript differ $(P<0.05)$.

${ }^{\text {A-E }}$ Means within a column with no common uppercase superscript differ $(P<0.05)$.

${ }^{1} \mathrm{FFC}=$ Full-fat control; RFC $=$ reduced-fat control; RF-JFR 1 = reduced-fat cheese made with the ropy culture Lactococcus lactis ssp. cremoris JFR1; RF-Slab = reduced-fat cheese made with the capsule-forming nonropy strain Streptococcus thermophilus Slab; RF-3534 = reduced-fat cheese made with the moderate ropy strain Streptococcus thermophilus CHCC 3534; and RF-5842 = reduced-fat cheese made with the EPSnegative genetic variant Streptococcus thermophilus CHCC 5842.

Bourne, 1978). The gumminess was lower $(P<0.05)$ in fresh FFC and RF-JFR1 than in all other reduced-fat cheeses and it was higher $(P<0.05)$ in RF-JFR1 than in FFC (Table 3). During the first month of ripening, although gumminess slightly increased in FFC and decreased in RF-JFR1, a sharp decrease in its value was observed in all other reduced-fat cheeses. After 6 mo of ripening, full-fat cheese exhibited the lowest gumminess, followed by reduced-fat cheeses made with EPSproducing cultures (RF-JFR1, RF-Slab, and RF-3534).

\section{Chewiness}

Chewiness is the energy required to chew a solid food product to a state where it is ready for swallowing (Szczesniak et al., 1963; Bourne, 1978). The chewiness was lower $(P<0.05)$ in fresh FFC and RF-JFR1 than in all other reduced-fat cheeses (Table 3). Furthermore, no significant differences were observed between the fresh FFC and RF-JFR1. During the first month of ripening, a sharp decrease $(P<0.05)$ in chewiness was observed in all cheeses except FFC and RF-JFR1, which remained unchanged. After 6 mo of ripening, full-fat cheese had the lowest chewiness. Cheeses made with EPS-producing cultures were much less chewy than those made with no EPS. There is a correlation between cheese hardness and chewiness-harder cheese is more difficult to chew (Beal and Mittal, 2000). Fat reduction increased both parameters. However, reduced-fat cheeses made with EPS-producing cultures were the least affected by fat reduction.

\section{Softening and Flow Characteristics}

The changes in the softening and flow characteristics of cheeses made with EPS-producing and nonproducing cultures are shown in Table 4. Fresh FFC and RF-JFR1 cheeses melted and softened in a shorter time and at lower temperatures than did all other reduced-fat cheeses. Protein-protein interactions during heating affect the melting and flow properties of cheese (Lucey et al., 2003). The loss of cheese elasticity during heating results in softening while flow occurs when the viscous modulus becomes greater than the elastic modulus ( $\mathrm{Lu}-$ cey et al., 2003). The low MNFS in all reduced-fat cheeses except RF-JFR1 could be responsible for their lower meltability. Similar observations were reported for Mozzarella cheese (McMahon et al., 1999). The higher the MNFS, the lower the protein concentration and number of intermolecular bonds. This produces less viscous and shorter cheese, which would melt faster (Lucey and Fox, 1993; Kuo et al., 2001). Zhou and Mulvaney (1998) also reported that the ratio of casein to water rather than the fat level had a major effect on meltability of casein gels. 
Table 4. Softening time, softening temperature, and flow rate of reduced- and full-fat Cheddar cheeses during ripening.

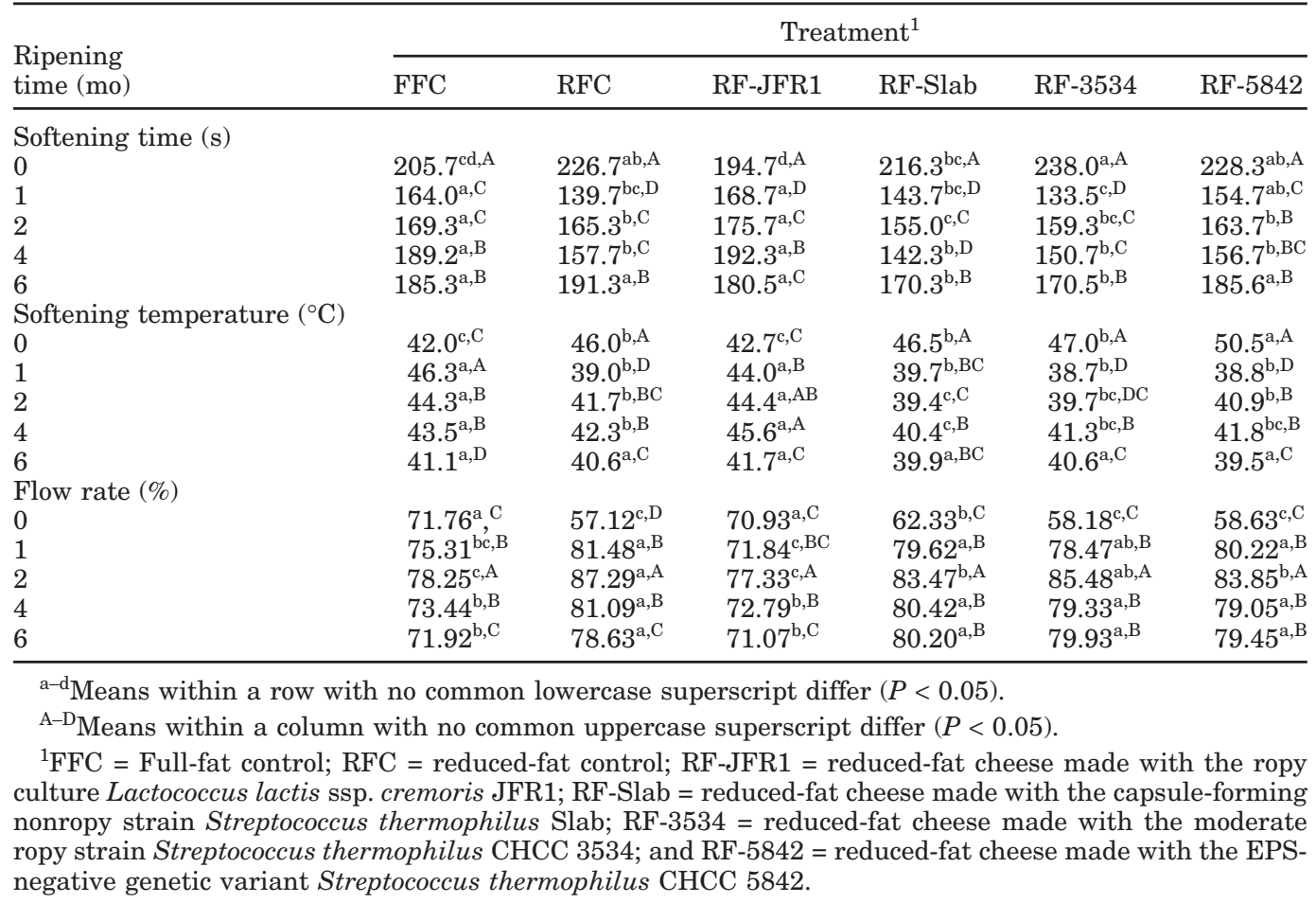

During ripening, major changes in softening time and temperature took place in all cheeses except FFC and RF-JFR1 (Table 4). No differences $(P>0.05)$ in softening time and temperature were observed among FFC, RFJFR1, and RF-5842 after 6 mo of ripening. This indicated that RF-5842 (no EPS) cheeses softened during ripening at a higher rate than either FFC and RF-JFR1. Muthukumarappan et al. (1999) also reported that meltability of reduced-fat cheese increased to a greater extent during ripening compared with full-fat cheese. In addition, Kuo et al. (2001) showed that the meltability was higher in 1-wk-old full-fat Cheddar cheese than in reduced-fat cheese, whereas the opposite was found after $6 \mathrm{wk}$ of ripening, as the meltability was higher in reduced- than in full-fat cheese. The casein matrix in cheese becomes softer and less elastic during ripening due to the breakdown of $\alpha_{\mathrm{s} 1}$-casein. However, because proteolysis was greater in RF-JFR1 and FFC than in all other reduced-fat cheeses (Awad et al., 2005), our results confirm the speculation of McMahon et al. (1999) that factors other than proteolysis, such as redistribution of water in cheese during storage, may also contribute to cheese softening. If solubilization of colloidal calcium phosphate was a major factor causing the decrease in the hardness of cheese during the first few weeks of ripening, one would expect FFC and RF-JFR1 cheeses, which showed the most significant decline in their $\mathrm{pH}$ (Awad et al., 2005), to show a significant change in their textural characteristics. However, these 2 cheeses did not exhibit any reduction in hardness during the first month of ripening. During the first weeks of ripening, expressible water is absorbed from the fat-serum channels of the cheese in the protein matrix, which becomes more hydrated and softer (McMahon et al., 1999). The softening results were consistent with the microstructure (Hassan and Awad, 2005) and hardness data. Microstructural observations showed that water redistribution was much less in FFC and RF-JFR1 than in all other cheeses. In addition, these 2 cheeses were the only types that did not become softer as they aged for 6 mo (Table 2).

The flow rates were higher in fresh FFC and RFJFR1 than in all other fresh cheeses (Table 4). There were no differences in the flow rates between the 6mo-old FFC and RF-JFR1 and the corresponding fresh ones. However, the flow rates of all other 6-mo-old reduced-fat cheeses were much higher than those of the corresponding fresh cheeses. Interestingly, FFC and RF-JFR1 had similar melting patterns, which were different from those of all other reduced-fat cheeses. The FFC and RF-JFR1 cheeses became soft and creamy without losing shape when heated, whereas reducedfat cheese made with EPS-nonproducing cultures ran and separated into solids and liquid. The similarity in the flow rate and pattern of these 2 types of cheeses might be due to the similar level of MNFS. 
Table 5. Flavor scores for reduced- and full-fat Cheddar cheeses during ripening.

\begin{tabular}{llllllll}
\hline & & \multicolumn{7}{c}{ Treatment $^{1}$} \\
\cline { 3 - 7 } Attribute & $\begin{array}{l}\text { Ripening } \\
\text { time (mo) }\end{array}$ & FFC & RFC & RF-JFR1 & RF-Slab & RF-3534 & RF-5842 \\
\hline Acid $^{2}$ & 1 & $3.9^{\mathrm{ab}, \mathrm{A}}$ & $2.6^{\mathrm{b}, \mathrm{C}}$ & $4.6^{\mathrm{a}, \mathrm{C}}$ & $3.4^{\mathrm{b}, \mathrm{C}}$ & $2.4^{\mathrm{b}, \mathrm{C}}$ & $3.1^{\mathrm{b}, \mathrm{C}}$ \\
& 3 & $3.7^{\mathrm{c}, \mathrm{B}}$ & $3.3^{\mathrm{c}, \mathrm{B}}$ & $5.0^{\mathrm{a}, \mathrm{B}}$ & $5.2^{\mathrm{a}, \mathrm{B}}$ & $4.5^{\mathrm{b}, \mathrm{B}}$ & $4.5^{\mathrm{b}, \mathrm{B}}$ \\
& 6 & $3.5^{\mathrm{b}, \mathrm{C}}$ & $5.0^{\mathrm{a}, \mathrm{A}}$ & $5.5^{\mathrm{a}, \mathrm{A}}$ & $6.5^{\mathrm{a}, \mathrm{A}}$ & $5.5^{\mathrm{a}, \mathrm{A}}$ & $5.5^{\mathrm{a}, \mathrm{A}}$ \\
Bitter $^{2}$ & 1 & $1.0^{\mathrm{a}, \mathrm{A}}$ & $1.0^{\mathrm{a}, \mathrm{B}}$ & $1.4^{\mathrm{a}, \mathrm{C}}$ & $1.0^{\mathrm{a}, \mathrm{C}}$ & $1.0^{\mathrm{a}, \mathrm{C}}$ & $1.0^{\mathrm{a}, \mathrm{C}}$ \\
& 3 & $1.0^{\mathrm{d}, \mathrm{A}}$ & $1.5^{\mathrm{d}, \mathrm{A}}$ & $5.5^{\mathrm{a}, \mathrm{A}}$ & $4.0^{\mathrm{b}, \mathrm{B}}$ & $3.0^{\mathrm{c}, \mathrm{B}}$ & $3.3^{\mathrm{c}, \mathrm{B}}$ \\
& 6 & $1.0^{\mathrm{b}, \mathrm{A}}$ & $1.5^{\mathrm{b}, \mathrm{A}}$ & $4.5^{\mathrm{a}, \mathrm{B}}$ & $4.5^{\mathrm{a}, \mathrm{A}}$ & $4.5^{\mathrm{a}, \mathrm{A}}$ & $4.5^{\mathrm{a}, \mathrm{A}}$ \\
Flat/Lacking $^{2}$ & 1 & $3.1^{\mathrm{a}, \mathrm{A}}$ & $4.7^{\mathrm{a}, \mathrm{A}}$ & $3.4^{\mathrm{a}, \mathrm{A}}$ & $4.9^{\mathrm{a}, \mathrm{A}}$ & $5.0^{\mathrm{a}, \mathrm{A}}$ & $4.3^{\mathrm{a}, \mathrm{A}}$ \\
& 3 & $2.2^{\mathrm{d}, \mathrm{B}}$ & $3.0^{\mathrm{c}, \mathrm{B}}$ & $3.8^{\mathrm{b}, \mathrm{A}}$ & $4.0^{\mathrm{b}, \mathrm{B}}$ & $4.5^{\mathrm{a}, \mathrm{B}}$ & $4.5^{\mathrm{a}, \mathrm{A}}$ \\
& 6 & $1.5^{\mathrm{b}, \mathrm{C}}$ & $1.5^{\mathrm{b}, \mathrm{C}}$ & $2.5^{\mathrm{a}, \mathrm{B}}$ & $2.5^{\mathrm{a}, \mathrm{C}}$ & $2.5^{\mathrm{a}, \mathrm{C}}$ & $2.5^{\mathrm{a}, \mathrm{B}}$ \\
Ovverall $^{3}$ & 1 & $6.4^{\mathrm{a}, \mathrm{B}}$ & $6.3^{\mathrm{a}, \mathrm{A}}$ & $6.2^{\mathrm{a}, \mathrm{A}}$ & $6.3^{\mathrm{a}, \mathrm{A}}$ & $6.0^{\mathrm{a}, \mathrm{A}}$ & $5.9^{\mathrm{a}, \mathrm{A}}$ \\
& 3 & $6.8^{\mathrm{a}, \mathrm{A}}$ & $6.2^{\mathrm{b}, \mathrm{A}}$ & $5.5^{\mathrm{c}, \mathrm{B}}$ & $5.0^{\mathrm{d}, \mathrm{B}}$ & $5.2^{\mathrm{cd}, \mathrm{B}}$ & $5.0^{\mathrm{d}, \mathrm{B}}$ \\
& 6 & $7.0^{\mathrm{a}, \mathrm{A}}$ & $5.5^{\mathrm{b}, \mathrm{B}}$ & $4.5^{\mathrm{b}, \mathrm{C}}$ & $3.5^{\mathrm{b}, \mathrm{C}}$ & $3.5^{\mathrm{b}, \mathrm{C}}$ & $3.5^{\mathrm{b}, \mathrm{C}}$ \\
\hline
\end{tabular}

${ }^{\mathrm{a}-\mathrm{d}}$ Means within a row with no common lowercase superscript $\operatorname{differ}(P<0.05)$.

${ }^{\mathrm{A}-\mathrm{C}}$ Means within a column with no common uppercase superscript $\operatorname{differ}(P<0.05)$.

${ }^{1} \mathrm{FFC}=$ Full-fat control; RFC = reduced-fat control; RF-JFR 1 = reduced-fat cheese made with the ropy culture Lactococcus lactis ssp. cremoris JFR1; RF-Slab = reduced-fat cheese made with the capsule-forming nonropy strain Streptococcus thermophilus Slab; RF-3534 = reduced-fat cheese made with the moderate ropy strain Streptococcus thermophilus CHCC 3534; and RF-5842 = reduced-fat cheese made with the EPSnegative genetic variant Streptococcus thermophilus CHCC 5842.

${ }^{2}$ Scale for flavor score: $1=$ none, $5=$ definite, and $9=$ pronounced.

${ }^{3}$ Scale for overall score: $1=$ poor, $5=$ average, and $9=$ excellent.

\section{Sensory Assessments}

The sensory evaluation results are shown in Tables 5 and 6 . There were no significant differences in flavor among all cheeses at 1 mo of ripening (Table 5). After 6 mo of ripening, FFC had the highest flavor score among all cheeses. Bitterness was definite in RF-JFR1 cheese after 3 mo of ripening and in all other reducedfat cheeses except RFC at 6 mo of ripening (Table 5). The acid, flat, and lack of typical Cheddar flavor were pronounced in all aged, reduced-fat cheeses except RFC. The FFC and RFC cheeses were the only 2 treatments made solely with commercial Cheddar starter.

At the 1-mo evaluation, panelists detected differences $(P<0.05)$ in body and texture between reduced-fat cheeses, except RF-JFR1, and FFC (Table 6). The FFC and RF-JFR 1 cheeses were less crumbly, curdy, grainy, and rubbery than all other reduced-fat cheeses. They were also described as short, smooth, and soft. The crumbliness, curdiness, graininess, and rubberiness of all cheeses decreased during ripening (Table 6). The aged RF-JFR1 and FFC cheeses received the highest scores for overall body and texture.

The main goal of this research was to select, among different EPS-producing cultures, the culture that produces reduced-fat Cheddar with similar textural and functional characteristics to its full-fat counterpart. Because the culture that gave the best results was not a typical Cheddar cheese starter, Cheddar cheese flavor did not develop. In current research in our laboratory, the JFR 1 culture is used in conjunction with other cul- tures known for their ability to accelerate ripening and remove bitterness in making reduced-fat Cheddar. In addition, because JFR1 produced young reduced-fat Cheddar cheese with sensory, textural, and functional characteristics similar to those of the full-fat type, we see potential applications of such cultures in making reduced-fat process cheeses.

\section{CONCLUSIONS}

Exopolysaccharide-producing cultures improved textural, melting, and sensory characteristics of reducedfat cheeses. A ropy Lactococcus lactis spp. cremoris strain (JFR1) produced reduced-fat Cheddar cheese with a MNFS level and textural and melting properties similar to those of the full-fat type. Changes in hardness and softening of both full-fat cheese and that made with the ropy strain followed the same pattern. Water redistribution seemed to be one of the major factors responsible for changes in the texture and softening of reduced-fat Cheddar cheese during the first few weeks of ripening. When cheese manufacturers try to increase MNFS in reduced-fat cheese to a level similar to that in the full-fat types, the cheese becomes pasty and difficult to shred. The ropy strain (JFR1) produced cheese with the same MNFS level as the full-fat type, yet maintained shreddable body. This is due to the ability of EPS to bind significant amounts of free water.

\section{ACKNOWLEDGMENTS}

This work was supported in part by the MinnesotaSouth Dakota Dairy Foods Research Center. The au- 
Table 6. Body and texture scores for reduced- and full-fat Cheddar cheeses during ripening.

\begin{tabular}{|c|c|c|c|c|c|c|c|}
\hline \multirow[b]{2}{*}{ Parameter } & \multirow{2}{*}{$\begin{array}{l}\text { Ripening } \\
\text { time (mo) }\end{array}$} & \multicolumn{6}{|c|}{ Treatment $^{1}$} \\
\hline & & FFC & $\mathrm{RFC}$ & RF-JFR1 & RF-Slab & RF-3534 & RF-5842 \\
\hline \multirow[t]{3}{*}{ Crumbly $^{2}$} & 1 & $2.0^{\mathrm{a}, \mathrm{A}}$ & $3.8^{\mathrm{a}, \mathrm{A}}$ & $2.0^{\mathrm{a}, \mathrm{A}}$ & $2.3^{\mathrm{a}, \mathrm{A}}$ & $3.9^{\mathrm{a}, \mathrm{A}}$ & $3.4^{\mathrm{a}, \mathrm{A}}$ \\
\hline & 3 & $1.4^{\mathrm{b}, \mathrm{B}}$ & $2.7^{\mathrm{a}, \mathrm{B}}$ & $1.3^{\mathrm{b}, \mathrm{B}}$ & $2.7^{\mathrm{a}, \mathrm{A}}$ & $3.1^{\mathrm{a}, \mathrm{A}}$ & $3.1^{\mathrm{a}, \mathrm{A}}$ \\
\hline & 6 & $1.0^{\mathrm{b}, \mathrm{C}}$ & $1.5^{\mathrm{a}, \mathrm{C}}$ & $1.0^{\mathrm{b}, \mathrm{B}}$ & $2.0^{\mathrm{a}, \mathrm{B}}$ & $2.0^{\mathrm{a}, \mathrm{B}}$ & $2.0^{\mathrm{a}, \mathrm{B}}$ \\
\hline \multirow{3}{*}{ Curdy $^{2}$} & 1 & $2.9^{\mathrm{b}, \mathrm{A}}$ & $5.7^{\mathrm{a}, \mathrm{A}}$ & $3.1^{\mathrm{b}, \mathrm{A}}$ & $4.9^{\mathrm{a}, \mathrm{A}}$ & $5.9^{\mathrm{a}, \mathrm{A}}$ & $5.9^{\mathrm{a}, \mathrm{A}}$ \\
\hline & 3 & $2.9^{\mathrm{b}, \mathrm{A}}$ & $4.0^{\mathrm{a}, \mathrm{B}}$ & $2.5^{\mathrm{b}, \mathrm{B}}$ & $4.2^{\mathrm{a}, \mathrm{B}}$ & $4.5^{\mathrm{a}, \mathrm{B}}$ & $4.5^{\mathrm{a}, \mathrm{B}}$ \\
\hline & 6 & $3.0^{\mathrm{b}, \mathrm{A}}$ & $3.5^{\mathrm{ab}, \mathrm{B}}$ & $1.0^{\mathrm{c}, \mathrm{C}}$ & $3.5^{\mathrm{ab}, \mathrm{B}}$ & $4.0^{\mathrm{a}, \mathrm{B}}$ & $3.0^{\mathrm{b}, \mathrm{C}}$ \\
\hline \multirow[t]{3}{*}{ Grainy $^{2}$} & 1 & $2.1^{\mathrm{ab}, \mathrm{A}}$ & $2.7^{\mathrm{a}, \mathrm{A}}$ & $1.9^{\mathrm{b}, \mathrm{A}}$ & $2.3^{\mathrm{ab}, \mathrm{A}}$ & $2.7^{\mathrm{a}, \mathrm{A}}$ & $2.7^{\mathrm{a}, \mathrm{A}}$ \\
\hline & 3 & $1.5^{\mathrm{b}, \mathrm{B}}$ & $1.7^{\mathrm{b}, \mathrm{B}}$ & $1.2^{\mathrm{b}, \mathrm{B}}$ & $2.0^{\mathrm{a}, \mathrm{B}}$ & $2.2^{\mathrm{a}, \mathrm{B}}$ & $2.2^{\mathrm{a}, \mathrm{B}}$ \\
\hline & 6 & $1.0^{\mathrm{b}, \mathrm{C}}$ & $1.0^{\mathrm{b}, \mathrm{C}}$ & $1.0^{\mathrm{b}, \mathrm{C}}$ & $2.0^{\mathrm{a}, \mathrm{B}}$ & $2.0^{\mathrm{a}, \mathrm{B}}$ & $2.0^{\mathrm{a}, \mathrm{B}}$ \\
\hline \multirow[t]{3}{*}{ Rubbery/firm ${ }^{2}$} & 1 & $2.7^{\mathrm{b}, \mathrm{A}}$ & $6.9^{\mathrm{a}, \mathrm{A}}$ & $3.0^{\mathrm{b}, \mathrm{A}}$ & $5.6^{\mathrm{a}, \mathrm{A}}$ & $7.0^{\mathrm{a}, \mathrm{A}}$ & $6.4^{\mathrm{a}, \mathrm{A}}$ \\
\hline & 3 & $2.2^{\mathrm{b}, \mathrm{B}}$ & $4.8^{\mathrm{a}, \mathrm{B}}$ & $1.9^{\mathrm{b}, \mathrm{B}}$ & $4.9^{\mathrm{a}, \mathrm{B}}$ & $5.0^{\mathrm{a}, \mathrm{B}}$ & $5.0^{\mathrm{a}, \mathrm{B}}$ \\
\hline & 6 & $1.5^{\mathrm{b}, \mathrm{C}}$ & $3.5^{\mathrm{ab}, \mathrm{C}}$ & $1.0^{\mathrm{b}, \mathrm{C}}$ & $4.5^{\mathrm{a}, \mathrm{B}}$ & $4.5^{\mathrm{a}, \mathrm{B}}$ & $4.0^{\mathrm{a}, \mathrm{C}}$ \\
\hline \multirow[t]{3}{*}{ Short $^{2}$} & 1 & $4.1^{\mathrm{a}, \mathrm{C}}$ & $3.9^{\mathrm{ab}, \mathrm{B}}$ & $4.3^{\mathrm{a}, \mathrm{C}}$ & $3.3^{\mathrm{ab}, \mathrm{B}}$ & $3.6^{\mathrm{ab}, \mathrm{A}}$ & $2.8^{\mathrm{b}, \mathrm{B}}$ \\
\hline & 3 & $5.0^{\mathrm{a}, \mathrm{B}}$ & $4.1^{\mathrm{b}, \mathrm{A}}$ & $5.5^{\mathrm{a}, \mathrm{B}}$ & $4.5^{\mathrm{b}, \mathrm{A}}$ & $3.5^{\mathrm{c}, \mathrm{A}}$ & $3.5^{\mathrm{c}, \mathrm{A}}$ \\
\hline & 6 & $7.0^{\mathrm{a}, \mathrm{A}}$ & $4.5^{\mathrm{b}, \mathrm{A}}$ & $6.0^{\mathrm{a}, \mathrm{A}}$ & $4.5^{\mathrm{b}, \mathrm{A}}$ & $2.5^{\mathrm{c}, \mathrm{B}}$ & $2.5^{\mathrm{c}, \mathrm{B}}$ \\
\hline \multirow[t]{3}{*}{ Smooth $^{2}$} & 1 & $5.4^{\mathrm{a}, \mathrm{B}}$ & $2.3^{\mathrm{b}, \mathrm{C}}$ & $5.2^{\mathrm{a}, \mathrm{B}}$ & $3.1^{\mathrm{b}, \mathrm{B}}$ & $2.6^{\mathrm{b}, \mathrm{B}}$ & $2.9^{\mathrm{b}, \mathrm{B}}$ \\
\hline & 3 & $5.5^{\mathrm{a}, \mathrm{B}}$ & $3.4^{\mathrm{b}, \mathrm{B}}$ & $5.9^{\mathrm{a}, \mathrm{A}}$ & $3.4^{\mathrm{b}, \mathrm{A}}$ & $3.4^{\mathrm{b}, \mathrm{A}}$ & $3.4^{\mathrm{b}, \mathrm{A}}$ \\
\hline & 6 & $6.0^{\mathrm{a}, \mathrm{A}}$ & $4.5^{\mathrm{b}, \mathrm{A}}$ & $6.0^{\mathrm{a}, \mathrm{A}}$ & $4.0^{\mathrm{b}, \mathrm{A}}$ & $4.0^{\mathrm{b}, \mathrm{A}}$ & $4.0^{\mathrm{b}, \mathrm{A}}$ \\
\hline \multirow[t]{3}{*}{ Weak/soft ${ }^{2}$} & 1 & $2.6^{\mathrm{a}, \mathrm{A}}$ & $1.2^{\mathrm{a}, \mathrm{B}}$ & $2.8^{\mathrm{a}, \mathrm{A}}$ & $1.8^{\mathrm{a}, \mathrm{A}}$ & $1.3^{\mathrm{a}, \mathrm{B}}$ & $1.7^{\mathrm{a}, \mathrm{A}}$ \\
\hline & 3 & $2.0^{\mathrm{a}, \mathrm{B}}$ & $1.5^{\mathrm{b}, \mathrm{B}}$ & $2.5^{\mathrm{a}, \mathrm{A}}$ & $1.7^{\mathrm{b}, \mathrm{A}}$ & $1.7^{\mathrm{b}, \mathrm{A}}$ & $1.7^{\mathrm{b}, \mathrm{A}}$ \\
\hline & 6 & $1.5^{\mathrm{a}, \mathrm{C}}$ & $2.0^{\mathrm{a}, \mathrm{A}}$ & $1.5^{\mathrm{a}, \mathrm{B}}$ & $1.5^{\mathrm{a}, \mathrm{B}}$ & $1.5^{\mathrm{a}, \mathrm{A}}$ & $1.5^{\mathrm{a}, \mathrm{B}}$ \\
\hline \multirow[t]{3}{*}{ Overall $^{3}$} & 1 & $7.0^{\mathrm{a}, \mathrm{B}}$ & $4.0^{\mathrm{c}, \mathrm{B}}$ & $6.8^{\mathrm{a}, \mathrm{B}}$ & $5.3^{\mathrm{b}, \mathrm{A}}$ & $4.1^{\mathrm{bc}, \mathrm{B}}$ & $4.2^{\mathrm{bc}, \mathrm{C}}$ \\
\hline & 3 & $7.0^{\mathrm{a}, \mathrm{B}}$ & $4.20^{\mathrm{c}, \mathrm{B}}$ & $7.0^{\mathrm{a}, \mathrm{B}}$ & $5.5^{\mathrm{b}, \mathrm{A}}$ & $4.5^{\mathrm{c}, \mathrm{A}}$ & $4.5^{\mathrm{c}, \mathrm{B}}$ \\
\hline & 6 & $7.8^{\mathrm{a}, \mathrm{A}}$ & $4.5^{\mathrm{b}, \mathrm{A}}$ & $7.2^{\mathrm{a}, \mathrm{A}}$ & $4.5^{\mathrm{b}, \mathrm{B}}$ & $4.5^{\mathrm{b}, \mathrm{A}}$ & $5.0^{\mathrm{ab}, \mathrm{A}}$ \\
\hline
\end{tabular}

a,b,c Means within a row with no common lowercase superscript differ $(P<0.05)$.

${ }_{\mathrm{A}, \mathrm{B}, \mathrm{C}}$ Means within a column of same parameter, with no common uppercase superscript $\operatorname{differ}(P<0.05)$.

${ }^{1} \mathrm{FFC}=$ Full-fat control; RFC = reduced-fat control; RF-JFR1 = reduced-fat cheese made with the ropy culture Lactococcus lactis ssp. cremoris JFR1; RF-Slab = reduced-fat cheese made with the capsule-forming nonropy strain Streptococcus thermophilus Slab; RF-3534 = reduced-fat cheese made with the moderate ropy strain Streptococcus thermophilus CHCC 3534; and RF-5842 = reduced-fat cheese made with the EPSnegative genetic variant Streptococcus thermophilus CHCC 5842.

${ }^{2}$ Scale for body and texture scores: $1=$ none, $5=$ definite, and $9=$ pronounced.

${ }^{3}$ Scale for overall scores: 1 = poor, $5=$ average, and $9=$ excellent.

thors would like to thank Chr. Hansen (Hørsholm, Denmark and Milwaukee, WI) for providing starter cultures.

\section{REFERENCES}

Anderson, D. L., V. V. Mistry, R. L. Brandsma, and K. A. Baldwin. 1993. Reduced fat Cheddar cheese from condensed milk. 1. Manufacture, composition, and ripening. J. Dairy Sci. 76:2832-2844.

Awad, S., A. N. Hassan, and F. Halaweish. 2005. Application of exopolysaccharide-producing cultures in reduced fat Cheddar cheese: Composition and proteolysis. J. Dairy Sci. 88:4195-4203.

Beal, P., and G. S. Mittal. 2000. Vibration and compression responses of Cheddar cheese at different fat content and age. Milchwissenschaft 55:139-142.

Bourne, M. 1978. Texture Profile Analysis. Food Technol. 32:6266,72 .

Broadbent, J. R., D. J. McMahon, D. L. Welker, C. J. Oberg, and S. Moineau. 2003. Biochemistry, genetics, and applications of exopolysaccharide production Streptococcus thermophilus: A review. J. Dairy Sci. 86:407-423.

Bryant, A., Z. Ustunol, and J. Steffe. 1995. Texture of Cheddar cheeses as influenced by fat reduction. J. Food Sci. 60:1216-1219.

Cerning, J. 1990. Exocellular polysaccharides produced by lactic acid bacteria. FEMS Microbiol. Rev. 87:113-130.

De Jong, L. 1978. The influence of the moisture content on the consistency and protein breakdown of cheese. Neth. Milk Dairy J. 32:1-14.
De Vuyst, L., F. Vanderverken, S. Van de Van, and B. Degeest. 1998. Production by an isolation of exopolysaccharides from Streptococcus thermophilus grown in a milk medium and evidence for their growth-associated biosynthesis. J. Appl. Microbiol. 84:1059-1068.

Drake, M. A., G. W. Barbosa-Canovas, and B. G. Swanson. 1996. Viscoelastic properties of reduced-fat and full-fat Cheddar cheeses. J. Food Sci. 61:821-823.

Gorret, N. J., L. Maubois, J. M. Engasser, and M. Ghoul. 2001. Study of the effects of temperature, $\mathrm{pH}$ and yeast extract on growth and exopolysaccharide production by Propionibacterium acidipropionici on milk microfiltrate using a response surface methodology. J. Appl. Microbiol. 90:788-796.

Guinee, T. P. 2002. Cheese Rheology. Pages 341-349 in Encyclopedia of Dairy Science. H. Roginski, J. W. Fuquay, and P. F. Fox, ed. Academic Press, London, UK.

Guinee, T. P., M. A. E. Auty, and M. A. Fenelon. 2000. The effect of fat content on the rheology, microstructure and heat-induced functional characteristics of Cheddar cheese. Int. Dairy J. 10:277-288.

Hassan, A. N., and S. Awad. 2005. Application of exopolysaccharideproducing cultures in reduced fat Cheddar cheese: Cryo-scanning electron microscopy observations. J. Dairy Sci. 88:4214-4220.

Hassan, A. N., M. Corredig, J. F. Frank, and M. El-Soda. 2004. Microstructure and rheology of an acid-coagulated cheese (Karish) made with an exopolysaccharide-producing Streptococcus thermophilus strain and its exopolysaccharide non-producing genetic variant. J. Dairy Res. 71:116-120.

Hassan, A. N., and J. F. Frank. 1997. Modification of microstructure and texture of rennet curd by using a capsule-forming nonropy lactic culture. J. Dairy Res. 64:115-121. 
Hassan, A. N., J. F. Frank, and M. El-Soda. 2003. Observation of bacterial exopolysaccharide in dairy products using cryo-scaning electron microscopy. Int. Dairy J. 13:755-762.

Hassan, A. N., J. F. Frank, M. A. Farmer, K. A. Schmidt, and S. I. Shalabi. 1995. Observation of encapsulated lactic acid bacteria using confocal scanning laser microscopy. J. Dairy Sci. 78:2624-2628.

Irudayaraj, J., M. Chen, and D. I. McMahon. 1999. Texture development in Cheddar cheese during ripening. Can. Agric. Eng. 41:253-258.

Jameson, M. E. 1990. Cheese with less fat. Aust. J. Dairy Technol. 11:93-98.

Kanawjia, S. K., P. Rajesh, L. Sabikhi, and S. Singh. 1995. Flavor, chemical and texture profile changes in accelerated ripened Gouda cheese. Lebensm. Wiss. Technol. 28:577-583.

Kuo, M. I., Y. C. Wang, S. Gunasekaran, and N. F. Olson. 2001. Effect of heat treatments on the meltability of cheeses. J. Dairy Sci. 84:1937-1943.

Lawrence, R. C., and J. Gilles. 1987. Cheddar cheese and related dry-salted cheese varieties. Pages 1-44 in Cheese: Chemistry, Physics, and Microbiology. Vol. 1. P. Fox, ed. Elsevier Applied Science Publishers, New York, NY.

Lucey, J. A., and P. F. Fox. 1993. Importance of calcium and phosphate in cheese manufacture: A review. J. Dairy Sci. 76:1714-1724.

Lucey, J. A., M. E. Johnson, and D. S. Horne. 2003. Perspectives on the basis of the rheology and texture properties of cheese. J. Dairy Sci. 86:2725-2743.

Ma, L., M. A. Drake, G. V. Barbosa-Canovas, and B. G. Swanson. 1997. Rheology of full-fat and low-fat Cheddar cheese as related to type of fat mimetic. J. Food Sci. 62:748-752.
Mayes, J. J., G. E. Urbach, and B. J. Sutherland. 1994. Does addition of buttermilk affect the organoleptic properties of low-fat cheese? Aust. J. Dairy Technol. 49:39-41.

McMahon, D. C., R. L. Fife, and C. J. Oberg. 1999. Water partitioning in Mozzarella cheese and its relationship to cheeses meltability. J. Dairy Sci. 82:1361-1369.

Mistry, V. V. 2001. Low fat cheese technology. Int. Dairy J. 11:413-422.

Mistry, V. V., and D. L. Anderson. 1993. Composition and microstructure of commercial full-fat and low-fat cheeses. Food Struct. $12: 259-266$

Muthukumarappan, K., Y. C. Wang, and S. Gunasekaran. 1999. Estimating softening point of cheeses. J. Dairy Sci. 82:2280-2286.

Olson, N. F., and M. E. Johnson. 1990. Light cheese products: Characteristics and economics. Food Technol. 44:93-96.

Pastorino, A. J., C. L. Hansen, and D. J. McMahon. 2003. Effect of salt on structure-function relationships of cheese. J. Dairy Sci. 86:60-69.

Perry, D. B., D. J. McMahon, and C. J. Oberg. 1998. Manufacture of low fat Mozzarella cheese using exopolysaccharide-producing starter cultures. J. Dairy Sci. 81:563-566.

Prentice, J. H., K. R. Langley, and R. J. Marshall. 1993. Cheese rheology. Pages 303-640 in Cheese: Chemistry, Physics, and Microbiology. Vol. 1. P. F. Fox, ed. Chapman \& Hall, London, UK.

SAS Institute. 1999. User's Guide: Statistics. Version 8 ed. SAS Inst., Inc., Cary, NC.

Szczesniak, A., M. Brandt, and H. Freidman. 1963. Development of standard rating scales for mechanical parameters and correlation between the objective and sensory texture measurements. Food Technol. 22:50-54

Zhou, N., and S. J. Mulvaney. 1998. The effect of milk fat, the ratio of casein to water, and temperature on the viscoelastic properties of rennet casein gels. J. Dairy Sci. 81:2561-2571. 